\title{
Dependencies between Variables from the Area of the Monetary and Fiscal Policy in the European Union Countries
}

\author{
Joanna Stawska (iD) https://orcid.org/0000-0001-6863-1210 \\ Ph.D., University of Lodz, Faculty of Economics and Sociology \\ Department of Central Banking and Financial Intermediation, Lodz, Poland \\ e-mail: joanna.stawska@uni.lodz.pl
}

\begin{abstract}
Research background: The core of coordinating a monetary and fiscal policy (policy mix) is based on combining both policies to achieve goals related to price stability, as well as economic growth and employment. In turn, the decisions of economic authorities in the monetary-fiscal game have a significant impact on economic variables in the economy. In the economic literature, the importance of monetary and fiscal policy coordination is emphasized as it has a positive effect on the stability of the economy. Purpose of the article: The aim of the article is to identify the dependencies between variables in the scope of fiscal policy and monetary policy under existing economic conditions and then assess their impact on the economy in the EU countries.

Methods: To achieve this objective, the following research methods were used: a review of the scientific literature, a presentation of statistical data, and statistical research methods.

Findings \& Value added: The rationale for adopting such issues is to examine the impact of the financial crisis on the decisions of central banks and governments in the EU. The financial crisis has affected a change in the approach to conducting monetary and fiscal policy. The changing economic conditions forced economic authorities to take many decisions that affected the interaction between the central bank and the governments in the EU Member States. In many EU countries in the discussed period, there were significant interdependencies between variables in both monetary and fiscal policy.
\end{abstract}

Keywords: fiscal policy, monetary policy, coordination, European Union

JEL: E00, E52, E62 


\section{Introduction}

The decisions of economic authorities (central bank and governments) in monetary and fiscal policy influence each other and also economic variables in the economy. As a result of the monetary and fiscal game of decision-makers striving to achieve their different goals and preferences, different policy mix combinations arise, which do not always positively impact the stability of the economy. Hence, the economic literature emphasizes that coordinating monetary and fiscal policy positively affects the stability of a given economy. The interaction between monetary policy and fiscal policy variables is influenced by many factors, often independent of economic authorities such as financial crises.

Therefore, the purpose of the article is to identify the interaction between fiscal and monetary policy under existing economic conditions and then assess their impact on the economy in the EU countries. To achieve the goal, the following research methods were used: a review of the scientific literature, a presentation of statistical data, and statistical research methods. The article verifies the hypothesis that interdependencies between policy mix variables in many EU countries are relevant. During the analyzed period, between 2004-2018, the EU Member States experienced a financial and economic crisis, which influenced many monetary and fiscal policy decisions. The article underlines the impact of the economic crisis on economic variables in the field of policy mix in the EU countries. In numerous EU Member States, there were significant interdependencies between variables in the field of monetary and fiscal policy in the discussed period, which may indicate the existence of significant interactions of decision-making economic authorities.

The structure of the paper is as follows. Section One presents the findings of a review of studies on the monetary and fiscal game in the economy. Section Two contains an analysis of selected monetary and fiscal policy variables in the EU countries. Section Three presents a study on the interaction of variables in the policy mix in the EU Member States. The last section concludes.

\section{Literature review}

There are numerous interdependencies (interactions) between monetary and fiscal policy. These interactions occur in three dimensions: (1) the institutions (decision-makers), (2) the targets, and (3) the instruments. The first level covers the relations between the entities responsible for implementing the monetary and fiscal policy, i.e., the central bank and the government. The second level refers to the objectives pursued by the institutions, while the monetary and fiscal authorities usually have different goals, which is the reason for conflicts. Referring to the third level, i.e., instruments available to decision-makers, we stress that each of them, using separate instruments, influences the economy in various ways and with a different time lag. The relationship between 
monetary and fiscal policy can be partially described using the monetary policy instrument as the interest rate. By setting the interest rate, the central bank considers the potential impact of deficit and public debt on the level of prices and interest rates, among others (Hughes Hallett et al. 2014). In economic practice, monetary and fiscal authorities use a specific combination of instruments by determining the policy mix or "mix" of economic policy tools (Clarida et al. 2000; Samuelson and Nordhaus 2010, pp. 139-199).

The central bank is responsible for monetary policy, while the government is responsible for fiscal policy. Both policymakers set their goals, which in the case of the central bank, is most often inflation; the government deals with production or employment levels. Both parties also determine their preferences, which correspond to the weightings in the loss functions of both authorities, recorded in formulas 1 and 2 (Dixit and Lambertini 2003, pp. 1522-1542):

Formula 1:

$$
L_{F}=\frac{1}{2}\left[\left(\pi-\pi_{F}\right)^{2}+\theta_{F}\left(y-y_{F}\right)^{2}+2 \delta x\right]
$$

Formula 2:

$$
L_{M}=\frac{1}{2}\left[\theta_{M}\left(y-y_{M}\right)^{2}+\left(\pi-\pi_{M}\right)^{2}\right]
$$

where $L_{F}$ - the social loss function for the fiscal authorities, which the government is trying to minimize; $L_{M}$ - the loss function for the monetary authorities that the monetary authority minimizes; $y$ and $\pi$ are the current levels of production and inflation, $y_{M}$ - the central bank's output target; $y_{F}$ - a GDP that minimizes social losses or the effective level of production; $\pi_{F}$ - the average level of fixed prices in the economy, which is socially optimal to minimize price differentiation; $\pi_{M}$ - the inflation target for the monetary authorities; $x$ - fiscal policy; and $\theta_{F}, \theta_{M}, \delta$-parameters relating to production.

In order to achieve an equilibrium of the game, the minimum loss function of each decision-maker should be determined, taking into account the limitations resulting from the structure of the economy and the actions of the other player. Considering the instruments of the central bank and the government, the reaction function of both players can be determined, and comparing these functions leads to equilibrium (Cechetti 2000, pp. 43-59).

In the fiscal-monetary game with the Nash equilibrium, two players of equal status select a strategy under the assumption that the partner's strategy is known. Neither player can one-sidedly improve their situation as they each believe that their strategy is optimal (Woroniecka-Leciejewicz 2015). The fiscal-monetary game presented as a matrix in Table 1 shows how important it is for the monetary authorities and the fiscal authorities to cooperate with each other, but it also demonstrates that 
such cooperation is not easy to establish because the central bank usually aims to ensure the stability of prices, whereas the government seeks to keep economic growth high and unemployment low (Buiter and Panigirtzoglou 1999; Bhattacharya and Kudoh 2002).

Table 1. The monetary-fiscal game: results and payoffs

\begin{tabular}{|c|c|c|}
\hline & $\begin{array}{c}\text { Restrictive central bank monetary } \\
\text { policy }\end{array}$ & $\begin{array}{l}\text { Expansionary central bank monetary } \\
\text { policy }\end{array}$ \\
\hline $\begin{array}{l}\text { Restrictive } \\
\text { government } \\
\text { fiscal policy }\end{array}$ & $\begin{array}{l}\text { Result: low inflation and low employ- } \\
\text { ment } \\
\text { Payoff: } \\
\text { central bank: } 6+1=7 \\
\text { government: } 3+1=4\end{array}$ & $\begin{array}{l}\text { Result: moderate inflation and moder- } \\
\text { ate employment } \\
\text { Payoff: } \\
\text { central bank: } 4+2=6 \\
\text { government: } 2+4=6\end{array}$ \\
\hline $\begin{array}{l}\text { Expansionary } \\
\text { government } \\
\text { fiscal policy }\end{array}$ & $\begin{array}{l}\text { Result: moderate inflation and moder- } \\
\text { ate employment } \\
\text { Payoff: } \\
\text { central bank: } 4+2=6 \\
\text { government: } 2+4=6\end{array}$ & $\begin{array}{l}\text { Result: high inflation and high employ- } \\
\text { ment } \\
\text { Payoff: } \\
\text { central bank: } 1+3=4 \\
\text { government: } 1+6=7\end{array}$ \\
\hline
\end{tabular}

Source: Bennett and Loayza 2001, p. 301.

Bennett and Loayza (2001) presented the monetary and fiscal game in the form of the matrix of this game, thus illustrating the strategic choices of the decision-makers, i.e., the central bank and the government. Both players can apply a restrictive or expansionary policy, which leads to different policy mix variants. Each decision-maker receives a different payment for individual results, i.e., each player receives a different value of the loss function. Players have different preferences regarding inflation and unemployment. For a given result, i.e., the level of unemployment and inflation, the players receive different payments. The central bank receives the highest payment for low inflation and the government for low unemployment.

In the fiscal-monetary game, the central bank's payoffs for low, medium, or high inflation are 6,4 , and 1 , respectively. The payoffs for low, medium, and high employment are 1,2, and 3. In the case of the fiscal authorities, low, medium, and high inflation involves payoffs of 3,2 , and 1 , and the payoffs for low, medium, and high employment are 1, 4, and 6 (Bennett and Loayza 2001, p. 301).

In response to the central bank adopting an expansionary monetary policy, the government may introduce an expansionary fiscal policy. Then the central bank earns the lowest score of 4 . Guessing what the government's strategy may be, the central bank goes for a restrictive monetary policy. To improve its situation, the government adopts an expansionary policy, which gives both authorities the same payoff of 6 (Table 1).

This matrix of the fiscal-monetary game well illustrates the degree of communication and collaboration problems that may result from their different goals (Van Aarle et al. 1995; Bhattacharya et al. 1998). For many economists, a coordinated monetary policy and fiscal policy are one of the best policy mix options. A lack of such coordi- 
nation was criticized by, for instance, Nordhaus (1994, pp. 139-199). Moreover, Corsetti et al. (2016b, pp. 1-29) emphasized that in the event of a strong recession shock, a common monetary and fiscal policy may be necessary for a satisfactory stabilization of the economy. Corsetti et al. (2016a, pp. 151-160) hold a similar position, claiming that monetary policy cannot achieve the goals of stabilization without stronger support for fiscal policies.

Hein and Truger (2014, pp. 21-38) argue that post-Keynesian management of macroeconomic policy must be characterized by close coordination of fiscal and monetary tools. This is particularly true of a currency union such as the euro area, since the central bank's main instrument, i.e., the interest rate, cannot be adapted to the requirements of each country. Moreover, De Bonis and Della Posta (2009, pp. 214-263) show that countries that are members of the monetary union can increase prosperity by coordinating their actions even if one is much smaller than the other and the group is affected by an asymmetrical shock.

When analyzing the interactions of variables in the area of monetary policy and fiscal policy, the issue of time lags, which characterize the economic policy implementation process, should also be taken into account because they are an element that disturbs monetary-fiscal interactions (Havranek and Rusnák 2013). In our study, we will focus on correlative relationships between policy mix variables to investigate whether these variables interact with each other.

\section{Data and research methodology}

The research period covers the years 2004-2018. Ten countries joined the EU in 2004; therefore, this year was considered the beginning of the research period. In this period, the financial crisis of 2008-2009 began, which then turned into a public finance crisis. It was followed the long-term return of countries to the path of equilibrium of public finances expressed as GG (General Government) deficit to GDP.

In this part of the article, attention is focused on selected variables that characterize monetary and fiscal policy. Monetary policy variables include short-term interest rates, such as the three-month interbank rate (on an annual basis) in the EU Member States (IR) and inflation as the HICP measure - the annual average rate of change (HICP). In turn, the variables in fiscal policy include real GDP growth - the percentage change on the previous year (GDP growth), and General Government (GG) Deficit as a percentage of GDP (DEFICIT). The article verifies the hypothesis that interdependencies between policy mix variables in many EU countries are relevant. This means that they exist and are statistically significant.

In the context of the monetary and fiscal interactions, Pearson's correlation ratios between the monetary policy variables (IR, HICP) and fiscal policy variables (GDP growth, DEFICIT) were calculated for all EU countries between 2004 and 2018 to check between which variables there are significant monetary and fiscal interactions 
(Table 6). The variables were tested for stationarity with the ADF test (Dickey-Fuller test). The time series of the analyzed variables turned out to be stationary only when using the first variable differences. Variables were transformed into first differences, yielding stationary series. In addition, the significance of correlations was also examined - a p-value $<0.05$ indicates significance at the $5 \%$ confidence level, and a p-value $<0.1$ indicates significance at the $10 \%$ level. The time series are also normally distributed.

\section{Results of the empirical research}

\section{Analysis of selected variables in the area of monetary and fiscal policy in the EU countries, 2004-2018}

Short-term interest rates in the EU countries varied significantly between 2004 and 2018 (Table 2), with the lowest interest rates in the euro-area countries. In 2004 , the short-term interest rate was $2.1 \%$, while in 2018 , it dropped below zero (-0.3\%). In 2007-2008 in the euro-area countries, the $3 \mathrm{M}$ interbank rate rose to $4.3 \%$ and $4.6 \%$, respectively, which was influenced by the inflation increase above the inflation target $(\leq 2 \%)$ in the euro area countries. In turn, the highest short-term interest rates were recorded in Romania, where in 2004 it was $19.1 \%$, and $12.3 \%$ and $11.3 \%$ in 2008 and 2009, respectively. The short-term interest rate in Romania began to gradually decline after 2010 (6.5\%), reaching 2.9\% in 2018.

In comparison to other EU countries, high interest rates were recorded in Hungary. In 2004, it was $11.5 \%$, and during the financial crisis, it was $8.8 \%$ in 2008 and 9.1\% in 2009. Starting from 2010, short-term interest rates in Hungary started to fall, reaching $1 \%$ in 2016 and $0.1 \%$ in 2018 . Relatively high interest rates were also recorded in Bulgaria (4.9\% in 2007, 7.1\% in 2008, and 5.7\% in 2009) during the financial crisis, while between 2014 and 2016, these rates fluctuated below $0.8 \%$ (reaching $0.0 \%$ in 2018). Croatia, Poland, and the United Kingdom recorded interest rates higher than in the other EU countries in the analyzed period - especially before the crisis and during the financial crisis. The period 2016-2018 saw the highest short-term interest rates in Poland (1.7\%). 
Dependencies between Variables from the Area of the Monetary and Fiscal Policy...

m

$m-\nabla m$ m

0

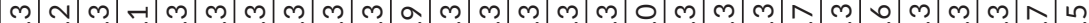

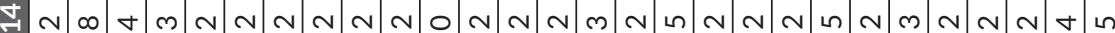

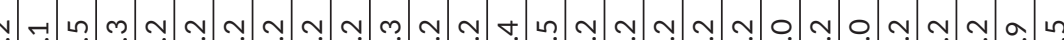

○

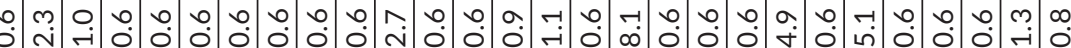

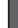

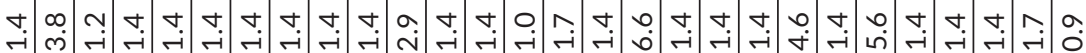

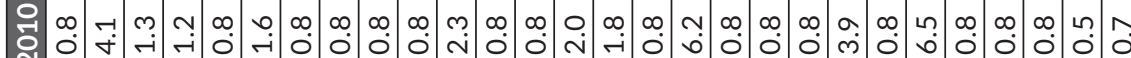

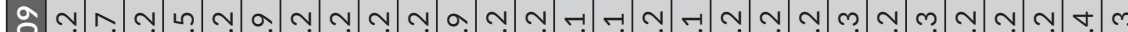
유

$\subseteq$

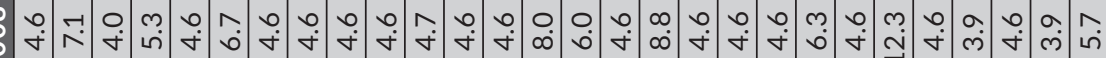
오

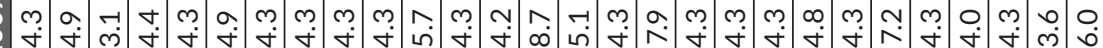

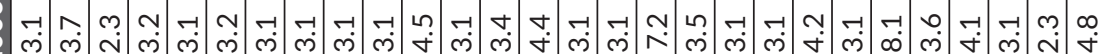

s c.

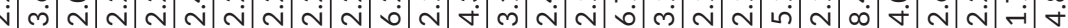

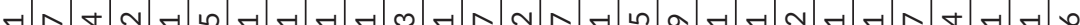

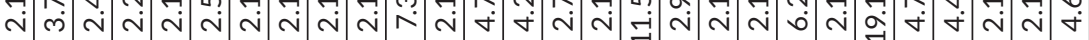

$\varepsilon$

प्र

$\frac{1}{\frac{1}{2}}$

i

$\frac{0}{\frac{0}{0}}$

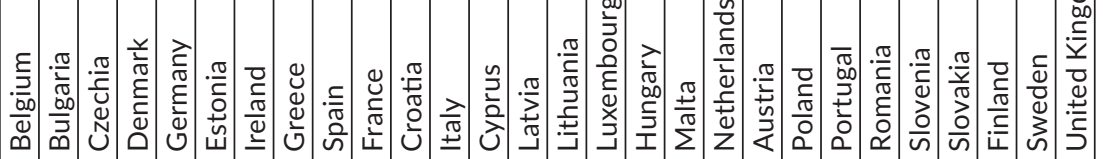


Table 3 presents the HICP inflation level as a monetary policy variable in the EU countries between 2004 and 2018. The countries with the highest inflation are Romania $(11.9 \%$ in $2004,9.1 \%$ in 2005 , and $7.9 \%$ in 2008$)$, Latvia $(6.2 \%$ in $2004,6.9 \%$ in $2005,10.1 \%$ in 2007 , and $15.3 \%$ in 2008), Bulgaria (6.1\% in 2004, 7.4\% in 2006, 7.6\% in 2007 , and $12 \%$ in 2008), Hungary (11.9\% in $2004,9.1 \%$ in $2005,6.6 \%$ in 2006 , and $7.9 \%$ in 2008), as well as Estonia (6.7\% in 2007, and $10.6 \%$ in 2008) and Lithuania (11.1\% in 2008). In these EU countries, inflation increased during the financial crisis, and these countries did not belong to the euro area. During the financial crisis, in the euro-area countries, inflation also rose, yet the highest value was observed in Slovenia (5.5\% in 2008, although Slovenia only joined the eurozone in 2007), Malta (4.7\% in 2008, which was Malta's entry to the euro area), Belgium (4.5\% in 2008), and Cyprus (4.4\% in 2008, the year of Cyprus's accession to the euro area). After the financial crisis, inflation fell sharply in most EU countries, and deflation was still observed in many countries in 2016. In 2018, the highest level of inflation was recorded in Romania (4.1\%) and the lowest in Denmark and Ireland (0.7\%). 
m

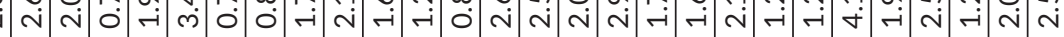

N N

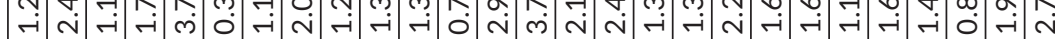

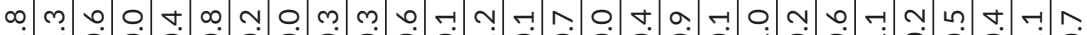

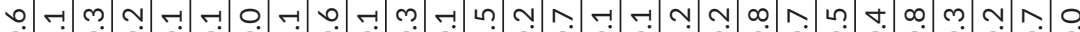

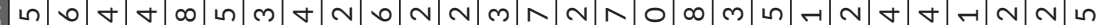

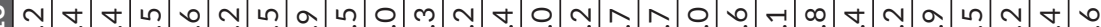

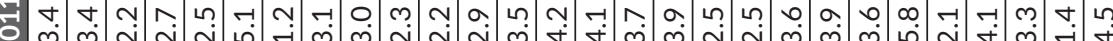

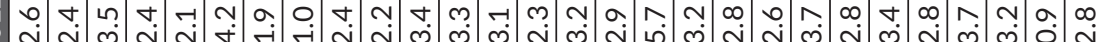

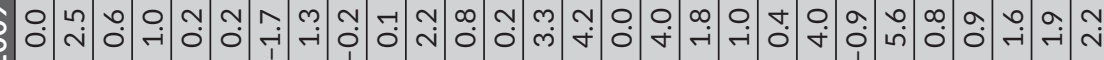

$\infty$ n 0 m

ส .

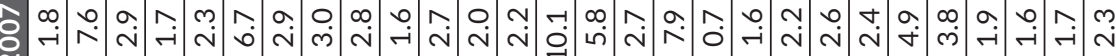

ะำ

$m$ m

N $\dot{N}$ N

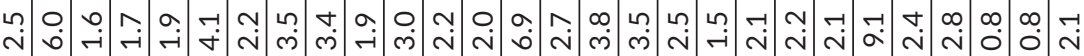

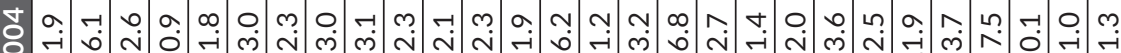


Table 4 presents the real GDP growth rate as a percentage change on the previous year as a variable in fiscal policy. Observing data on GDP growth, during the 20082009 economic crisis, only Poland recorded a GDP increase between 2008 and 2009. After the financial crisis, the economic growth rate decreased significantly, and some countries, such as Italy, recorded a lower GDP growth than before the financial crisis. The economic performance, especially during the 2008-2009 crisis and after this period, required appropriate fiscal and monetary policies to stimulate economic growth.

In many EU countries, including Poland, in the face of challenges that emerged in connection with the financial crisis, monetary and fiscal authorities took coordinated actions to stimulate the economy. For example, the central bank introduced additional operations to support liquidity in the interbank market, and it lowered interest rates to stimulate economic activity. Meanwhile, it recommended a prudent lending and deposit policy for banks. In turn, in the initial phase of the crisis, the government increased budget spending, particularly spending on investments, and introduced legislative changes to stop unemployment and stimulate economic growth (Stawska and Grzesiak 2014, p. 148; Stawska 2017, pp. 205-210).

During the financial crisis (2008-2009), the lowest economic growth was recorded by Lithuania, Estonia, and Latvia (respectively: $-14.8 \% ;-14.7 \% ;-14.4 \%$ ). Then, as a result of the public debt crisis, the largest decreases in GDP were recorded by Greece (-9.1\% in 2011), Portugal (-4.0\% in 2012), Spain (-2.9\% in 2012), Italy (-2.8\% in 2012$)$, and Cyprus (-5.8\% in 2013). In 2018, the highest economic growth in the EU was recorded by Ireland (8.2\%) and Malta (7.3\%). 
؟

Fิ

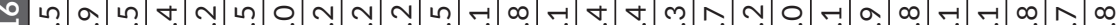

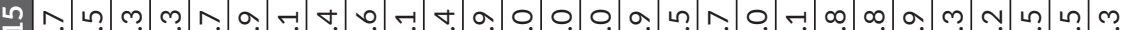

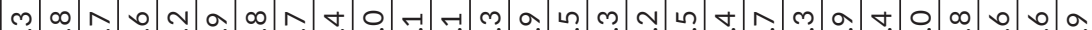

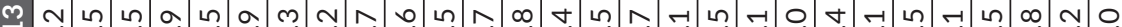

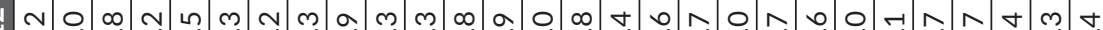

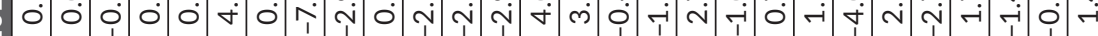

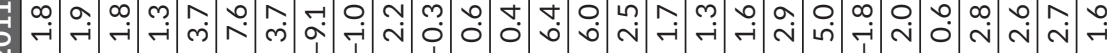

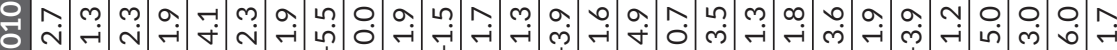

(a)

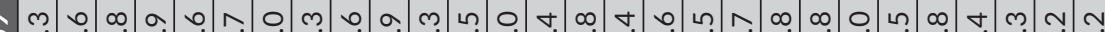

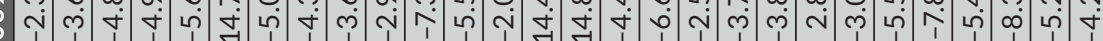

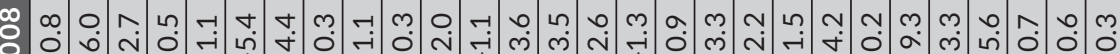

オ. m.

mं

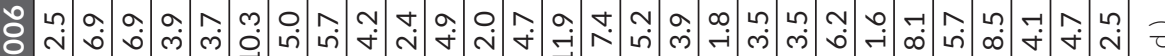

テr

\& an 
GG deficit is another variable in fiscal policy. The data on GG deficit in the EU countries that are presented in Table 5 cover the period between 2004-2018. The countries with the highest public deficit in the financial crisis in the EU are Greece, Portugal, Ireland, France, Latvia, Lithuania, Spain, and the United Kingdom. Additionally, in particular in 2014, also Cyprus, where the public deficit criterion (3\%) was successively exceeded.

After the crisis period of 2008-2009, the number of countries that exceeded the limits of public deficit significantly increased. The countries with the lowest GG deficit in 2004-2018 were Estonia, Sweden, and Luxembourg. Countries that did not meet the Maastricht criterion for GG deficit in 2016-2017 include only Spain, France, and Malta. In 2018, all European Union countries recorded GG deficits below 3\% of GDP (Maastricht criterion).

Finally, it is necessary to justify the expansionary fiscal policy in the crisis period in many EU countries, which limited the negative effects of the recession; however, these actions contributed to growing deficits and public debt in many countries, and as a consequence, they may cause inflationary pressure (van Riet A. 2010, pp. 7-34). 


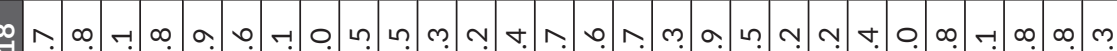

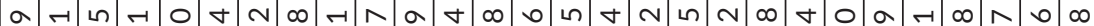

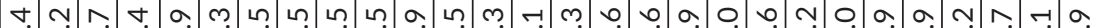

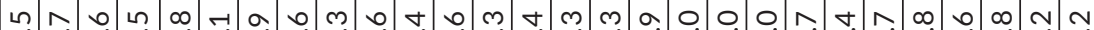

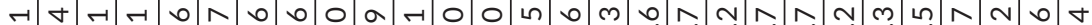

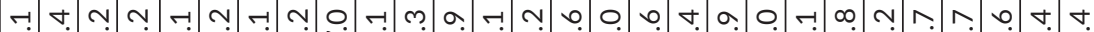

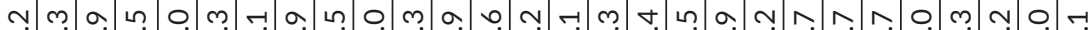

N 0 N 난.

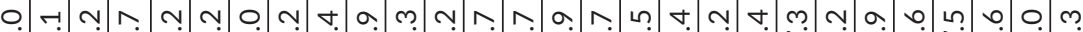

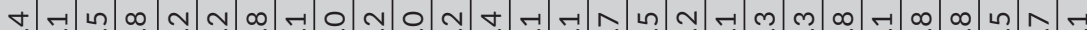
유

ம்

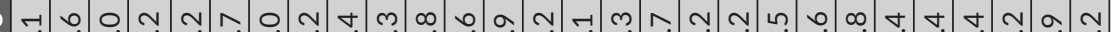

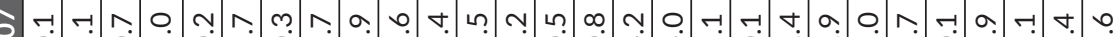

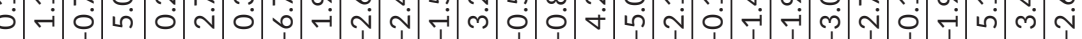




\section{The interactions of variables from the monetary and fiscal policies in the EU countries}

A negative correlation between GDP growth and short-term interest rate lagged by one year (IR (-1)), in accordance with the theory of economics that occurred in the discussed period in some EU countries. There is a high negative (statistically significant) correlation in most of the 28-EU Member States, apart from Ireland, Greece, Croatia, Cyprus, Latvia, Lithuania, and Hungary (where the correlations are not statistically significant). The lack of a statistically significant correlation between GDP growth and the interest rate lagged by one period may be related to the weak impact of monetary policy on economic growth in those countries and a stronger influence of other variables on economic growth.

Research on the monetary policy transmission mechanism in Poland indicates that the reaction of economic activity to a change in the short-term interest rate is the strongest and the fastest in the recovery phase of the economy, and the slowest and the weakest in a recession. The maximum reaction of the annual GDP dynamics occurs about half a year after the change in the interest rate - the GDP growth rate decreases between 0.1 and 0.3 percentage points (Chmielewski et al. 2018, p. 27). Thus, in countries where the recession phase lasted the longest or significantly affected the economic performance, the relationship between economic growth and the short-term interest rate could be weak, or it might not occur at all.

Table 6. Pearson's correlation ratios between selected monetary and fiscal policy variables in EU countries in 2004-2018

\begin{tabular}{|l|c|c|c|c|}
\hline \multicolumn{1}{|c|}{ Country } & $\begin{array}{c}\text { d_GDP growth } \\
\text { vs d_IR(-1) }\end{array}$ & $\begin{array}{c}\text { d_GDP growth } \\
\text { vs d_HICP }\end{array}$ & $\begin{array}{c}\text { d_DEFICIT } \\
\text { vs d_IR }\end{array}$ & $\begin{array}{c}\text { d_DEFICIT } \\
\text { vs d_HICP }\end{array}$ \\
\hline Belgium & $-0.8(p=0.001)^{*}$ & 0.2 & $0.6(p=0.019)$ & $0.4(p=0.127)$ \\
\hline Bulgaria & $-0.8(p=0.001)$ & $0.7(p=0.003)$ & 0.1 & $0.7(p=0.004)$ \\
\hline Czechia & $-0.7(p=0.003)$ & 0.3 & 0.2 & 0.3 \\
\hline Denmark & $-0.8(p<0.001)$ & $0.4(p=0.191)$ & $0.5(p=0.061)$ & 0.3 \\
\hline Germany & $-0.8(p=0.001)$ & $0.5(p=0.057)$ & $0.8(p=0.001)$ & $0.6(p=0.017)$ \\
\hline Estonia & $-0.6(p=0.026)$ & $0.4(p=0.197)$ & $-0.5(p=0.034)$ & -0.2 \\
\hline Ireland & -0.3 & 0.0 & 0.3 & $0.5(p=0.066)$ \\
\hline Greece & -0.1 & -0.1 & 0.3 & $0.4(p=0.173)$ \\
\hline Spain & $-0.7(p=0.006)$ & $0.4(p=0.162)$ & $0.5(p=0.078)$ & $0.4(p=0.191)$ \\
\hline France & $-0.9(p<0.001)$ & $0.5(p=0.049)$ & $0.8(p=0.001)$ & $0.6(p=0.013)$ \\
\hline Croatia & 0.2 & 0.1 & -0.2 & $0.4(p=0.136)$ \\
\hline Italy & $-0.8(p<0.001)$ & 0.2 & $0.7(p=0.003)$ & 0.3 \\
\hline Cyprus & $-0.4(p=0.115)$ & 0.3 & $0.4(p=0.133)$ & 0.2 \\
\hline Latvia & $-0.4(p=0.141)$ & 0.2 & $-0.4(p=0.190)$ & $0.4(p=0.136)$ \\
\hline Lithuania & -0.2 & 0.2 & $-0.5(p=0.091)$ & 0.1 \\
\hline Luxembourg & $-0.7(p=0.003)$ & 0.1 & $0.8(p<0.001)$ & 0.3 \\
\hline Hungary & -0.1 & -0.1 & $0.4(p=0.129)$ & $0.6(p=0.020)$ \\
\hline Malta & $-0.5(p=0.048)$ & 0.1 & -0.2 & $-0.5(p=0.049)$ \\
\hline
\end{tabular}




\begin{tabular}{|l|c|c|c|c|}
\multicolumn{1}{|c|}{ Country } & $\begin{array}{c}\text { d_GDP growth } \\
\text { vs d_IR(-1) }\end{array}$ & $\begin{array}{c}\text { d_GDP growth } \\
\text { vs d_HICP }\end{array}$ & $\begin{array}{c}\text { d_DEFICIT } \\
\text { vs d_IR }\end{array}$ & $\begin{array}{c}\text { d_DEFICIT } \\
\text { vs d_HICP }\end{array}$ \\
\hline Netherlands & $-0.7(p=0.005)$ & 0.1 & $0.8(p=0.001)$ & $0.4(p=0.191)$ \\
\hline Austria & $-0.7(p=0.002)$ & $0.7(p=0.008)$ & $0.7(p=0.002)$ & $0.7(p=0.007)$ \\
\hline Poland & $-0.7(p=0.010)$ & 0.0 & $0.4(p=0.150)$ & 0.1 \\
\hline Portugal & $-0.7(p=0.008)$ & 0.2 & $0.7(p=0.005)$ & $0.5(p=0.076)$ \\
\hline Romania & $-0.7(p=0.006)$ & 0.3 & $-0.4(p=0.144)$ & -0.1 \\
\hline Slovenia & $-0.8(p=0.001)$ & $0.6(p=0.033)$ & 0.3 & 0.2 \\
\hline Slovakia & $-0.5(p=0.097)$ & 0.0 & $0.6(p=0.009)$ & $0.4(p=0.112)$ \\
\hline Finland & $-0.8(p=0.001)$ & 0.1 & $0.9(p<0.001)$ & $0.6(p=0.026)$ \\
\hline Sweden & $-0.9(p<0.001)$ & 0.2 & $0.5(p=0.055)$ & 0.3 \\
\hline United Kingdom & $-0.8(p<0.001)$ & 0.2 & $0.7(p=0.005)$ & 0.3 \\
\hline
\end{tabular}

If $p<0.1$, the correlation is statistically significant

Source: own elaboration.

In the theory and practice of economics, the view is that high inflation and deflation adversely affect the dynamics of long-term economic growth. There are also views, such as from von Hayek, among others, about the beneficial, stimulating effect of slow inflation processes on the economic growth rate, although, only in the short term (von Hayek 2006, p. 323). In the case of the correlation between GDP growth and the HICP inflation rate, we note that a positive, statistically significant correlation occurred in the discussed period in Bulgaria, Germany, France, Austria, and Slovenia. Thus, in these countries, with inflation rising - GDP increased, or with falling inflation - GDP decreased.

Moderate inflation reduces the real costs of servicing public debt, so the threat to the budget may be an increase in interest rates, and unexpected changes in inflation through the impact on the level of fiscal policy may hamper economic policy (Cherif and Hasanov 2012, pp. 3-4). We note a statistically significant positive correlation between GG deficit (DEFICIT) and short-term interest rate (IR) in the vast majority of the EU countries during the period considered. This dependence turned out to be negative and statistically significant in Estonia and Lithuania. In the case of the correlation between GG deficit (DEFICIT) and the inflation index (HICP), this relation was positive and statistically significant in Bulgaria, Germany, Ireland, France, Hungary, Austria, Portugal, and Finland, whereas it was negative in Malta.

Analyzing the correlations of selected variables in the EU countries (which indicate many dependencies between the studied variables), we can also observe countries like Greece, Croatia, Cyprus, and Latvia without any statistically significant correlations between the selected pairs of variables. Ahrend et al. (2006) found that using real short-term interest rates (as a proxy for the monetary stance) and the cyclically-adjusted primary balance (as a measure of fiscal stance), correlations show that changes in fiscal and monetary stance do not seem to be correlated systematically, either positively or negatively. A partial exception is the United States, where the monetary and the fiscal policy stance seem to have moved mostly in the same direction over the past 25 years. 


\section{Conclusions}

The crisis period had a negative impact on many economic variables in most European Union countries. As a consequence of the economic crisis in the EU countries, short-term interest rates even decreased to negative values; deflation occurred in many countries; much lower economic growths were recorded, and in many countries, unemployment and GG deficits increased significantly. Based on the correlation between variables in the area of monetary policy, i.e., (IR) and (HICP), and fiscal policy, i.e., (GDP growth) and (DEFICIT), in the European Union in the period between 2004 and 2018, it was noticed that there are statistically significant correlations between variables in the scope of the policy mix in many of the countries surveyed. This demonstrates that the interactions between monetary and fiscal policy are important for the economies of many countries. Therefore, it should be noted that the economic authorities making decisions in the sphere of monetary and fiscal policy interact with each other and thus affect the economy of a given country. Hence, the importance of properly conducting monetary and fiscal policies and their significance in economic processes in the EU countries should always be taken into account.

Considering the comparative aspects in the presented study, it should be emphasized that it is important that some countries that belong to both the EU and the euro area have an impact on the conduct of fiscal policy, while the monetary policy for these countries is conducted by the ECB. In turn, the EU countries that do not belong to the euro area conduct their own monetary and fiscal policies. This affects many relationships between the variables in monetary and fiscal policy. The following countries stand out: Belgium, Germany, Estonia, Spain, France, Italy, Luxembourg, Malta, the Netherlands, Austria, Portugal, Slovenia, Slovakia, and Finland (countries from the euro area). Meanwhile, Bulgaria, Czechia, Denmark, Poland, Romania, Sweden, and Great Britain (countries outside the euro area but in the EU) showed a negative correlation (statistically significant) between GDP growth and short-term interest rate lagged by one year. In countries such as Bulgaria, Germany, France, Austria, and Slovenia, a positive correlation (statistically significant) was noted between GDP growth and HICP.

Between 2004 and 2018, there is a positive, statistically significant correlation between the GG deficit and the short-term interest rate in countries such as Belgium, Luxembourg, Germany, the Netherlands, Austria, Portugal, Slovakia, France, Spain, Italy, Finland (countries from the euro area) and Denmark, Sweden and the United Kingdom (countries outside the euro area). A positive correlation (statistically significant) between GG deficit and inflation was recorded in the following countries: Germany, Ireland, France, Austria, Portugal, Finland (countries from the euro area), as well as in Bulgaria and Hungary (countries outside the euro area). Thus, in these countries, we note a statistically significant relationship between the examined variables in monetary and fiscal policy. 
In countries such as Croatia, Cyprus, Greece, and Latvia, we do not see any statistically significant correlations in any of the four pairs of variables studied. This may be due to the fact that these countries pursued monetary and fiscal policy weakly correlated in the period considered. Greece was plunged into an economic crisis in 2008, so the Greek government's decisions were mainly focused on paying off the state's debts. Based on the correlations carried out, we can confirm the coexistence of the studied variables (in monetary and fiscal policies) in most EU countries (including the euro area). Although we are not able to state which variable is the cause and which is the effect, we can conclude with what strength the variables are related to each other, which is the added value of the research carried out.

Some limitations of the study should be pointed out. There is a complex system of economic and political integration in the EU countries, including the asymmetry of budget cycles or political cycles and associated election opportunism. The factors that disturb the relationships between variables in monetary and fiscal policies include the diverse objectives and preferences of the economic authorities, delays in implementing fiscal and monetary policy, as well as internal and external economic impulses, such as financial crises.

This provides an area for future analysis, especially as the correlation coefficient does not give information on which variables are dependent and which are independent - thus, it would be worth performing regression analysis between the selected variables, panel research, or Granger causality tests.

\section{Acknowledgments}

The article is part of a research project financed by the National Science Centre, Poland (grant no. UMO - 2017/26/D/HS4/00954).

\section{References}

Aarle, B. van, Bovenberg, L., Raith, M. (1995), Monetary and fiscal policy interactions and debt stabilization, "Journal of Economics", 62 (2), pp. 111-140, https://doi.org /10.1007/BF01226006

Ahrend, R., Catte, P., Price, R. (2006), Interactions between monetary and fiscal policy: How monetary conditions affect fiscal consolidation, ECO/WKP 49, https://doi .org/10.2139/ssrn.1010655

Bennett, H., Loayza, N. (2001), Policy biases when the monetary and fiscal authorities have different objectives, Central Bank of Chile Working Papers, No. 66.

Bhattacharya, J., Kudoh, N. (2002), Tight Money policies and inflation revisited, "Canadian Journal of Economics", 35 (2), pp. 185-271, https://doi.org/10.1111/1540-59 82.00127 
Bhattacharya, J., Guzman, M., Smith, B.D. (1998), Some even more unpleasant monetarist arithmetic, "Canadian Journal of Economics", 31 (3), pp. 596-623, https:// doi.org/10.2307/136204

Buiter, W., Panigirtzoglou, N. (1999), Liquidity traps: how to avoid them and how to escape them, NBER Working Paper, 7245, https://doi.org/10.3386/w7245

Cechetti, S. (2000), Making monetary policy: objectives and rules, "Oxford Review of Economic Policy”, 16 (4), pp. 43-59, https://doi.org/10.1093/oxrep/16.4.43

Cherif, R., Hasanov, F. (2012), Public debt dynamics: the effects of austerity, inflation, and growth shocks, IMF Working Papers, No. 12/230, https://doi.org/10.5089/978 1475510553.001

Chmielewski, T., Kapuściński, M., Kocięcki, A., Łyziak, T., Przystupa, J., Stanisławska, E., Wróbel, E. (2018), Monetary transmission mechanism in Poland. What do we know in 2017?, NBP Working Paper, No. 286.

Clarida, R., Gali, J., Gertler, M. (2000), Monetary policy rules and macroeconomic stability: evidence and some theory, "Quarterly Journal of Economics”, 115 (1), pp. 147180, https://doi.org/10.1162/003355300554692

Corsetti, G., Higgins, M., Pesenti, P. (2016a), Policies and institutions for managing the aggregate macroeconomic stance of the eurozone, [in:] R. Baldwin, F. Giavazzi (eds.), How to Fix Europe's Monetary Union. Views of Leading Economists, CEPR Press, London.

Corsetti, G., Dedola, L., Jarociński, M., Maćkowiak, B., Schmidt, S. (2016b), Macroeconomic stabilization, monetary-fiscal interactions, and Europe's monetary union, ECB Working Paper, Vol. 1988.

De Bonis, V., Della Posta, P. (2009), Strategic Interactions Among Central Bank and National Fiscal Authorities in a Monetary Union Subject to Asymmetric country Shocks, “Open Economy Review”, 20, pp. 241-263, https://doi.org/10.1007/s11079 -007-9065-1

Dixit, A., Lambertini, L., (2003), Interactions of Commitment and Discretion in Monetary and Fiscal Policies, “American Economic Review”, 93 (5), pp. 1522-1542, https:// doi.org/10.1257/000282803322655428

Eurostat Warehouse Database (n.d.), https:/ec.europa.eu/eurostat/data/database (accessed: 5.12.2019).

Havranek, T., Rusnák, M. (2013), Transmission lags of monetary policy: a meta-analysis, "International Journal of Central Banking", 9 (4), https://doi.org/10.2139/Ss rn. 2188438

Hein, E., Truger, A. (2014), Fiscal policy and rebalancing in the euro area: a critique of the German debt brake from a Post-Keynesian perspective, "Panoeconomicus", 61 (1), pp. 21-38, https://doi.org/10.2298/PAN1401021H

Hughes Hallett, A., Libich, J., Stehlik, P. (2014), Monetary and fiscal policy interaction with various degrees of commitment, "Czech Journal of Economics and Finance", 64 (1), pp. 2-29.

Nordhaus, W.D. (1994), Policy games: coordination and independence in monetary and fiscal policies, "Brookings Papers on Economic Activity", 2, pp. 139-216, https://doi .org/10.2307/2534656 
OECD (2019), Short-term interest rates (indicator), https://data.oecd.org/interest/shor t-term-interest-rates.htm (accessed: 5.12.2019).

Samuelson, P., Nordhaus, W.D. (2010), Economics, The McGraw-Hill Companies, Boston.

Stawska, J. (2017), The impact of policy mix instruments on the Euro Area economy in the low interest rates environment, "Ad-Alta - Journal of Interdisciplinary Research", 7, pp. 205-210.

Stawska, J., Grzesiak, L. (2014), Challenges for policy mix in the context of the financial crisis - the case of Poland, "Journal of Finance and Financial Law", 4, pp. 137-150.

van Riet, A. (2010), Euro area fiscal policies and the crisis, "Occasional Paper Series ECB”, No. 109, pp. 7-34.

Von Hayek, F.A. (2006), The Constitution of Liberty, Routledge Classic, Milton Park, Abingdon.

Woroniecka-Leciejewicz, I. (2015), Equilibrium strategies in a fiscal-monetary game. A simulation analysis, "Operations Research and Decisions", 2, pp. 75-100.

\section{Zależności pomiędzy zmiennymi z zakresu polityki monetarnej i fiskalnej w krajach Unii Europejskiej}

Istota koordynacji polityki pieniężnej oraz fiskalnej (policy mix) opiera się na takiej kombinacji tych dwóch polityk gospodarczych, aby możliwe było osiągnięcie celów dotyczących zarówno stabilności cen, jak i wzrostu gospodarczego oraz zatrudnienia. Z kolei decyzje podejmowane w grze monetarno - fiskalnej władz gospodarczych w sposób istotny oddziałują na zmienne ekonomiczne w gospodarce. W literaturze ekonomii podkreśla się istotność koordynacji polityki monetarnej i fiskalnej co pozytywnie oddziałuje na stabilność gospodarki. Celem artykułu jest identyfikacja zależności pomiędzy zmiennymi z zakresu polityki fiskalnej i polityki monetarnej w istniejących warunkach ekonomicznych a następnie ich wpływ na gospodarkę w krajach UE. Do osiągnięcia postawionego celu wykorzystano następujące metody badawcze: przegląd literatury naukowej, prezentację danych statystycznych oraz statystyczne metody badawcze. Uzasadnieniem podjęcia danej tematyki jest zbadanie wpływu ostatniego kryzysu finansowo-gospodarczego na decyzje banków centralnych i rządów w krajach UE. Kryzys finansowy wpłynął na zmianę podejścia do prowadzenia polityki pieniężnej i fiskalnej. Zmieniające się warunki gospodarcze wymusiły podejmowanie wielu decyzji przez władze gospodarcze, które wpłynęły na interakcje pomiędzy bankiem centralnym a rządem w krajach UE. W wielu krajach UE w omawianym okresie zanotowano istotne współzależności pomiędzy zmiennymi z zakresu polityki pieniężnej i fiskalnej.

Słowa kluczowe: polityka fiskalna, polityka monetarna, koordynacja, Unia Europejska 